\title{
Inhibition of fludarabine metabolism by arabinosylcytosine during therapy*
}

\author{
Annette Kemena ${ }^{1}$, Varsha Gandhi ${ }^{1}$, Donna S. Shewach ${ }^{2}$, Michael Keating ${ }^{1}$, and William Plunkett ${ }^{1}$ \\ 1 The University of Texas M. D. Anderson Cancer Center, Houston, TX 77030, USA \\ 2 The University of Michigan Medical Center, Ann Arbor, MI 48109, USA
}

Received 29 May 1992/Accepted 3 August 1992

\begin{abstract}
Summary. The active 5'-triphosphate of arabinosyl-2fluoroadenine (F-ara-ATP) increases the anabolism of arabinosylcytosine (ara-C), whereas ara-C $5^{\prime}$-triphosphate inhibits the phosphorylation of arabinosyl-2-fluoroadenine (F-ara-A) in human leukemia cells in vitro. These interactions have a potential impact on drug scheduling. Clinical trials of relapsed leukemia in which fludarabine (F-ara-A 5 -monophosphate) and ara- $\mathrm{C}$ were given in sequence provided the opportunity to evaluate the effects of ara-C infusion on two sequelae: the pharmacokinetics of F-ara-A in plasma and that of F-ara-ATP in leukemia cells. First, F-ara-A pharmacokinetics were altered by ara-C infusion. This was visualized as a transient increase in F-ara-A plasma levels during the ara-C infusion that was given $4 \mathrm{~h}$ after fludarabine. The perturbation in F-ara-A plasma levels was dependent on the dose of ara-C. Second, peak F-ara-ATP concentrations were lower in leukemia cells of patients who received ara- $\mathrm{C}$ in addition to fludarabine as compared with those who received fludarabine alone. The terminal half-life of F-ara-A in plasma and the half-life of intracellular F-ara-ATP were reduced after the ara-C infusion in a concentration-dependent manner. Studies using purified deoxycytidine kinase support the conclusion that the increase in plasma levels of F-ara- $A$ is in part the result
\end{abstract}

\footnotetext{
* This work was supported in part by grants CA32839, CA46452, CA53311, and CA57629 from the National Cancer Institute, Department of Health and Human Services, by the German Research Association (DFG), and by a contract from Berlex Laboratories, Inc.
}

\begin{abstract}
Abbreviations: ara-C, 9- $\beta$-D-arabinofuranosylcytosine; ara-CTP, 9- $\beta$-Darabinofuranosylcytosine $5^{\prime}$-triphosphate; AUC, area under the concentration-time curve; $\mathrm{AUC}_{\mathrm{p}}$, increase in the $\mathrm{AUC}$ caused by perturbation; CLL, chronic lymphocytic leukemia; dCyd kinase, deoxycytidine kinase; $F$-ara- $A, 9-\beta$-D-arabinofuranosyl-2-fluoroadenine; fludarabine, F-araAMP, $9-\beta$-D-arabinofuranosyl-2-fluoroadenine 5 -monophosphate; Fara-ATP, 9- $\beta$-D-arabinofuranosyl-2-fluoroadenine $5^{\prime}$-triphosphate; $t_{1 / 2}$, half-life of elimination
\end{abstract}

Correspondence to: William Plunkett, Department of Medical Oncology, Box 52, The University of Texas M. D. Anderson Cancer Center, 1515 Holcombe Blvd. Houston, TX 77030, USA of an effective competition by ara-C for phosphorylation by this enzyme, leading to a perturbation of the pharmacokinetics of intracellular F-ara-ATP.

\section{Introduction}

Arabinosylcytosine (ara-C) is the main component in treatment protocols for acute myelogenous leukemia [19], whereas fludarabine is the most active single agent against low-grade lymphocytic malignancies, especially chronic lymphocytic leukemia (CLL) $[20,21]$. The metabolism and mechanisms of action of both compounds are closely related. The first step, which is rate-limiting in their phosphorylation to the respective active triphosphates, is mediated by deoxycytidine kinase (dCyd kinase) [2, 10, $24,26]$. The activity of this enzyme is regulated by the cellular nucleotide pools $[9,11,25]$. In addition, ara-C $5^{\prime}$-triphosphate (ara-CTP) may exert feedback inhibition on dCyd kinase $[7,14,28]$. In contrast, the $5^{\prime}$-triphosphate of fludarabine (F-ara-ATP) stimulates dCyd kinase activity both indirectly by lowering the deoxynucleotide pool through the inhibition of ribonucleotide reductase $[2,14$, 32] and by an apparent direct action on the enzyme [14]. A positive correlation between the cellular pharmacokinetics of ara-CTP in circulating leukemia blasts and the clinical response to treatment has been established $[12,13,18,30]$. Strategies were therefore sought to increase the accumulation of ara-CTP through metabolic modulation by fludarabine.

When incubated in vitro with arabinosyl-2fluoroadenine (F-ara-A), K562 cells or freshly isolated leukemic lymphocytes accumulated ara-CTP at a higher rate to greater concentrations than did cells exposed to ara- $\mathrm{C}$ alone $[14,15]$. On the basis of these studies, we designed three different treatment protocols for patients with CLL or acute leukemias, in which fludarabine was infused prior to ara-C. Ara-CTP accumulation was potenti- 


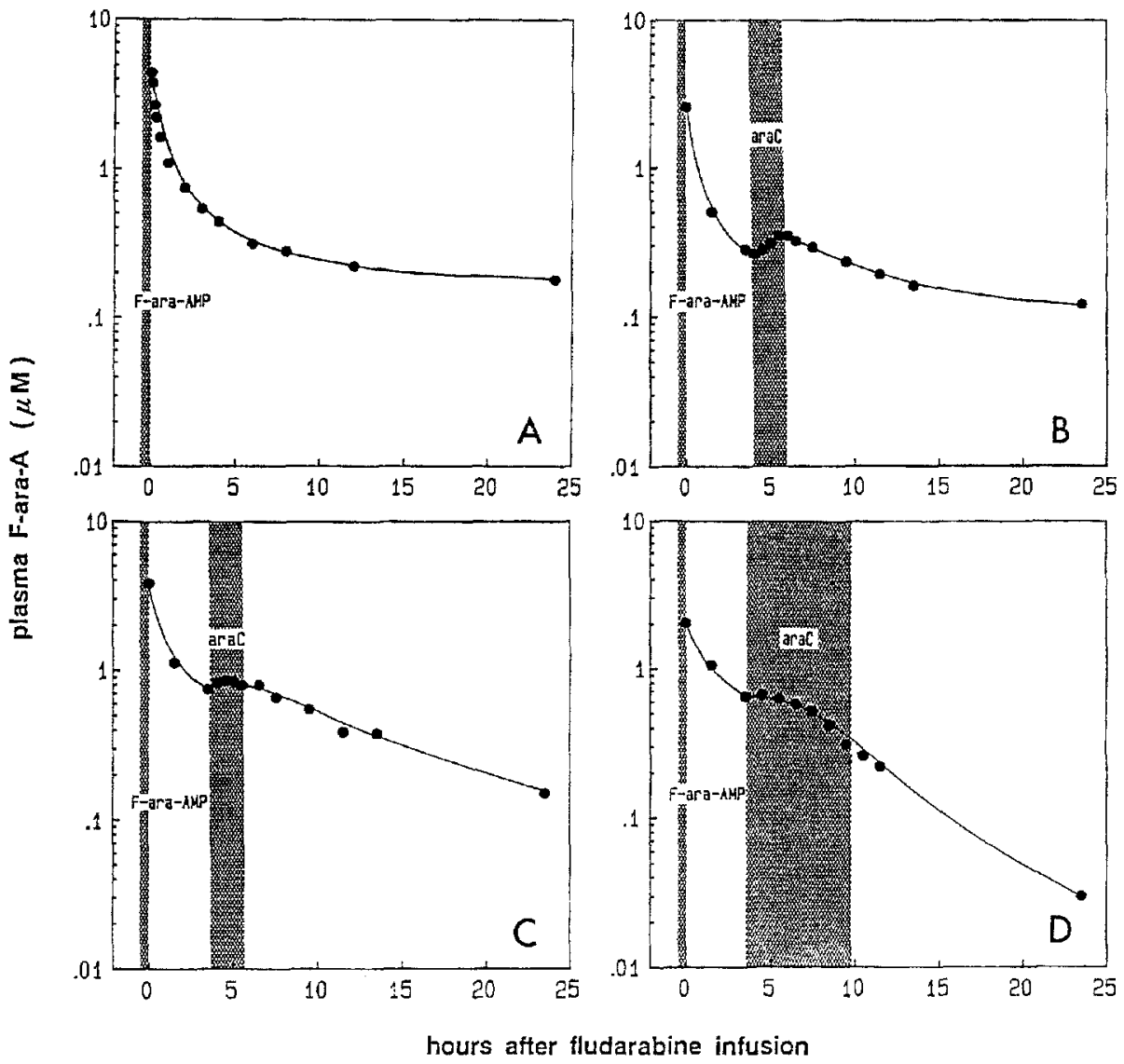

Fig. 1 A -D. Plasma concentrations of F-ara-A in four patients diagnosed with $\mathbf{A}$, B CLL or C, D acute leukemia were monitored over $24 \mathrm{~h}$ starting at the end of a 30 -min i. v. infusion of $30 \mathrm{mg} / \mathrm{m}^{2}$ fludarabine $(F$-ara- $A M P)$. Patients received fludarabine either $\mathbf{A}$ alone or in combination with two infusions of ara-C given (at $20 \mathrm{~h}$ before and $4 \mathrm{~h}$ after fludarabine) at doses of B 0.5, C 1 , and D $3 \mathrm{~g} / \mathrm{m}^{2}$. Each data point represents the result obtained in one plasma sample ated in circulating leukemia cells from patients who received the combination therapy $[16,17]$.

Studying the modulation of ara-C metabolism by fludarabine in clinical trials provided the opportunity to investigate two pharmacokinetic sequelae that have a potential impact on drug scheduling. First, on the basis of the kinetic characteristics of dCyd kinase, we hypothesized that the relatively high plasma concentrations of ara-C (>10 $\mu \mathrm{M})$ would compete effectively for phosphorylation against the lower levels of $\mathrm{F}$-ara-A $(0.3-0.7 \mu \mathrm{M})$, the nucleoside product of fludarabine dephosphorylation. Second, on the basis of studies in $\mathrm{K} 562$ cells, we expected that intracellular ara-CTP would inhibit F-ara-ATP accumulation, presumably through feedback inhibition of dCyd kinase. Thus, the pharmacokinetics of plasma F-ara-A and, consequently, of intracellular F-ara-ATP may be perturbed.

\section{Patients and methods}

Treatment. After informed consent had been obtained, patients were entered in one of the four treatment plans. Patients with refractory CLL received $30 \mathrm{mg} / \mathrm{m}^{2}$ fludarabine (F-ara-AMP, the clinical formulation of F-ara-A) in a $30-\min$ i. v. infusion either as a single agent $(n=6)$ or in combination with ara-C $\left(0.5 \mathrm{~g} / \mathrm{m}^{2}\right.$ given over $\left.2 \mathrm{~h}\right)$ infused at $20 \mathrm{~h}$ before and $4 \mathrm{~h}$ after the administration of fludarabine $(n=7)$. Adults with acute leukemia in relapse were treated with the same drug combination, except that the ara-C dose was either $1 \mathrm{~g} / \mathrm{m}^{2}$ infused over $2 \mathrm{~h}(n=6)$ or $3 \mathrm{~g} / \mathrm{m}^{2}$ infused over $6 \mathrm{~h}(n=6)$.

Materials. As chromatographic standards F-ara-A was supplied by Berlex Laboratories, Inc. (Alameda, Calif.) and [ $\left.8-{ }^{3} \mathrm{H}\right]-\mathrm{F}$-ara-A was obtained from Moravek Biochemicals (Brea, Calif.). F-ara-ATP was synthesized by Dr. A. Sen in this laboratory [29]. Ara-CTP and other ribonucleotides used as standards were purchased from Sigma (St. Louis, Mo). Erythro9-(2-hydroxy-3-nonyl)adenine was a gift from Dr. T. A. Krenitsky (Burroughs Wellcome, Research, Triangle Park, N.C.) and tetrahydrouridine was obtained from Dr. V. Narayanan of the Drug Synthesis and Chemistry Branch of the National Cancer Institute (Bethesda, Md.). The SEP-PAK $\mathrm{C}_{18}$ cartridges were supplied by Waters Associates (Milford, Mass.). All other chemicals used were of the highest purity available.

Preparation of plasma and peripheral mononuclear cells. Blood samples $(5-10 \mathrm{ml})$ obtained through a peripheral catheter were immediately transferred into a heparinized glass tube containing $1 \mu \mathrm{M}$ erythro-9-(2hydroxy-3-nonyl)adenine (to inhibit adenosine deaminase) and $500 \mu \mathrm{M}$ tetrahydrouridine (to inhibit cytidine deaminase), which was placed in an ice bath. After centrifugation at $500 \mathrm{~g}$ for $20 \mathrm{~min}$ at $4^{\circ} \mathrm{C}$, the plasma was removed and stored at $-20^{\circ} \mathrm{C}$. The cell pellet was resuspended in $40 \mathrm{ml}$ phosphate-buffered saline $\left(\mathrm{NaCl}, 8.1 \mathrm{~g} / \mathrm{N} ; \mathrm{Na}_{2} \mathrm{HPO}_{4}, 1.14 \mathrm{~g} / \mathrm{l} ; \mathrm{KCl}\right.$, $0.22 \mathrm{~g} / \mathrm{l} ; \mathrm{KH}_{2} \mathrm{PO}_{4}, 0.27 \mathrm{~g} / \mathrm{l}$ ) and layered over a $10-\mathrm{ml}$ Ficoll-Hypaque mixture (sp. gr., $1.077 \mathrm{~g} / \mathrm{ml}$ ). After centrifugation at $400 \mathrm{~g}$ for $20 \mathrm{~min}$ at $4^{\circ} \mathrm{C}$, the buoyant mononuclear cells were removed and diluted to $10 \mathrm{ml}$ with phosphate-buffered saline. Duplicate analyses of the mean cell number and cell volume were done with a model ZM Coulter counter equipped with a 100-channel particle-size analyzer (model C1000). Cellular nucleotides were extracted with $0.4 \mathrm{M} \mathrm{HClO}_{4}$, neutralized with $\mathrm{KOH}$, and stored at $-20^{\circ} \mathrm{C}[14]$.

Quantitation of nucleosides in plasma and cellular nucleotides. F-ara-A plasma levels were determined by high-pressure liquid chromatography with fluorescence detection using a method described in detail elsewhere [22]. In brief, the nucleoside was isolated from plasma by solid-phase extraction (elution from SEP-PAK $\mathrm{C}_{18}$ cartridges with alkaline methanol). After derivatization with chloroacetaldehyde to the fluorescent arabinosyl-etheno-isoguanine, the product was separated from other fluorescent compounds by reverse-phase high-pressure liquid chroma- 


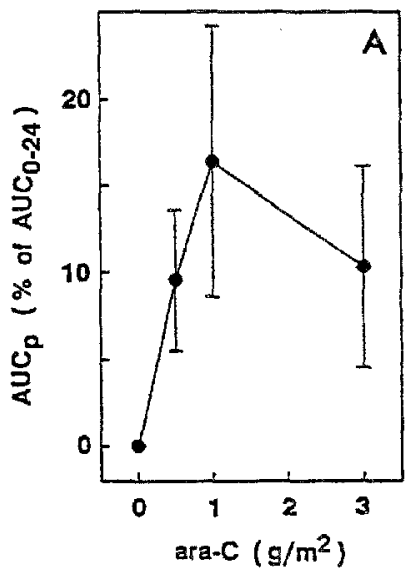

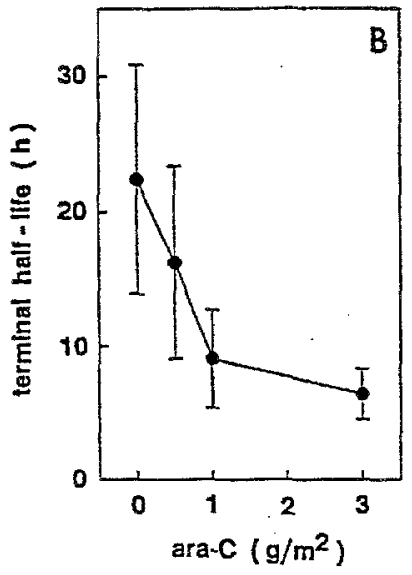

Fig. $2 \mathrm{~A}$, B. Influence of the ara-C dose on $\mathbf{A}$ the F-ara-A AUC and $\mathbf{B}$ the terminal half-life of $\mathrm{F}$-ara-A in plasma. Patients received two doses of ara-C, one at $20 \mathrm{~h}$ before fludarabine treatment and one at $4 \mathrm{~h}$ after the start of the fludarabine infusion. F-ara-A plasma concentrations were quantitated for up to $24 \mathrm{~h}$ after fludarabine infusion to calculate the AUC and elimination rates of $\mathrm{F}$-ara-A. The data point at $0 \mathrm{~g} / \mathrm{m}^{2}$ represents $\mathrm{F}$-ara-A pharmacokinetics when fludarabine was given as monotherapy. Each data point represents the mean $( \pm S D)$ increase in $A U C$ or terminal $t_{1 / 2}$ observed in 6 (no ara-C, 1 and $3 \mathrm{~g} / \mathrm{m}^{2}$ ara-C) or $7\left(0.5 \mathrm{~g} / \mathrm{m}^{2}\right.$ ara-C) patients tography ( $\mu$ Bondapak $\mathrm{C}_{18}$; Waters Associates, Milford, Mass.). F-ara-A concentrations in patient samples were calculated by comparing peak areas of the fluorescent derivative to those of standard samples spiked with $\mathrm{F}$-ara-A that had been processed simultaneously. Ara-C plasma levels were determined by reverse-phase high-pressure liquid chromatography according to the method described by Breithaupt [1]. The steady-state plasma ara-C concentration is expressed as the mean of the values obtained in the samples taken at $\mathrm{l}$ and $2 \mathrm{~h}$ ( 2 -h infusion) or, generally, as 1 - to $6-\mathrm{h}(6-\mathrm{h}$ infusion) values found for ara- $\mathrm{C}$ in plasma. The concentrations of intracellular ara-CTP and F-ara-ATP were determined by ion-exchange high-pressure liquid chromatography (Partisil-10 SAX column) with UV detection [14].

Pharmacokinetic data analysis. Analyses of pharmacokinetic data were performed using the computer program ESTRIP [3]. The F-ara-A plasma concentration-time data were stripped according to the i. v./postabsorption type, except for the samples that showed a transient increase in F-ara-A plasma levels. Then, the data sets were divided into two phases that were processed separately: the first phase, from the end of the infusion to the last time point prior to the increase in F-ara-A concentration, was stripped using the i.v./postabsorption type; the second phase, starting with the lowest concentration prior to the increase, was processed according to the absorption type. Both partial area under the curve (AUC) values were added to give the overall AUC. The increases in $A U C$ caused by ara-C perturbation of the $\mathrm{F}$-ara- $\mathrm{A}$ elimination kinetics $\left(\mathrm{AUC}_{\mathrm{p}}\right)$ were determined gravimetrically by overlaying the actual curve with a hypothetical, unperturbed elimination curve generated from the early data points (before perturbation) and the late data points ( $>10 \mathrm{~h}$ ). Elimination half-lives of perturbed F-ara-A concentration-time data sets were obtained by processing only the data acquired after the occurence of the peak or plateau concentration according to the i. v./postabsorption type. For pharmacokinetic analysis of intracellular F-ara-ATP, the concentration-time data were stripped according to the absorption type. The statistical significance of differences between the data sets was assessed by Student's two-tailed $t$-test.

Purification of dCyd kinase and determination of its activity. dCyd kinase was purified from a murine L-cell expression vector containing the cDNA sequence for the enzyme as described in detail elsewhere [6]. For determination of the $K_{\mathrm{i}}$ value (inhibition constant) for ara-C on dCyd kinase phosphorylation of F-ara-A, $15 \mu \mathrm{l}$ of the desalted enzyme was added to $15 \mu$ ice-cold reaction mix to achieve a final concentration of $50 \mathrm{~mm}$ imidazole/ $\mathrm{HCl}$ buffer ( $\mathrm{pH}$ 7.4), $25 \mathrm{~mm}$ dithiothreitol, $2 \mathrm{mM}$ ATP, $2.5 \mathrm{mu} \mathrm{MgCl} 2,100-600 \mu \mathrm{M}\left[{ }^{3} \mathrm{H}\right]-\mathrm{F}$-ara- $\mathrm{A}, 0-40 \mu \mathrm{M}$ ara-C, $1 \mathrm{mg}$ bovine serum albumin $/ \mathrm{ml}$ and $10 \%$ glycerol. After incubation for $20 \mathrm{~min}$ at $37^{\circ} \mathrm{C}$, the reaction was terminated by heating the sample for $1 \mathrm{~min}$ at $85^{\circ} \mathrm{C}$. The radiochemical quantitation of phosphorylated F-ara-A was performed as previously described [9]. Lines describing the double reciprocal plots were calculated according to a weighted fit program described by Wilkinson [35]. The resulting slope values were plotted against the ara-C concentrations, and the apparent $K_{\mathrm{i}}$ value was estimated from linear regression analysis.

\section{Results}

\section{Influence of ara-C infusion on the plasma pharmacokinetics of $F$-ara-A}

The plasma pharmacokinetics of F-ara-A was compared between patients receiving fludarabine as monotherapy and those additionally treated with an ara-C infusion. Figure 1 shows the data of four patients, each representative of the respective therapy group. The triphasic plasma-elimination kinetics of $\mathrm{F}$-ara- $\mathrm{A}$ in patients receiving fludarabine monotherapy (Fig. 1A) was perturbed by ara-C infusions in all three combination therapy protocols (Fig. 1B-D). The F-ara-A plasma levels either increased (Fig. 1 B, C) or plateaued (Fig. 1D) during the ara-C infusions. The increase in AUC caused by this transient rise in F-ara-A plasma concentration seemed to be dependent on the ara-C dose, with saturation occurring at $1 \mathrm{~g} / \mathrm{m}^{2}$ ara- $\mathrm{C}$ (Fig. 2A; $P=0.068$ for the difference between mean ${ }^{A U C} C_{p}$ values at $0.5 \mathrm{~g} / \mathrm{m}^{2}$ for $2 \mathrm{~h}$ vs $1 \mathrm{~g} / \mathrm{m}^{2}$ for $2 \mathrm{~h}$ ). At the same time, the terminal half-lives of F-ara-A decreased with increasing ara-C dose (Fig. 2B; $P=0.184$ at $0.5 \mathrm{~g} / \mathrm{m}^{2}$, $P=0.006$ at $1 \mathrm{~g} / \mathrm{m}^{2}$, and $P=0.001$ at $3 \mathrm{~g} / \mathrm{m}^{2}$ as compared with that obtained during fludarabine monotherapy). Although the total AUCs for F-ara-A over $24 \mathrm{~h}$ were increased after the various ara-C infusions $\left(0.5 \mathrm{~g} / \mathrm{m}^{2}\right.$, $9.2 \pm 3.2 \mu \mathrm{M} \mathrm{h} ; 1 \mathrm{~g} / \mathrm{m}^{2}, \quad 13.1 \pm 8.0 \mu \mathrm{M} \mathrm{h} ; 3 \mathrm{~g} / \mathrm{m}^{2}$, $12.4 \pm 5.2 \mu \mathrm{M} \mathrm{h})$ relative to that observed in the absence of ara-C $(7.4 \pm 3.6 \mu \mathrm{M} \mathrm{h})$, these changes were not statistically significant. These data suggest that ara-C caused a dose-related redistribution of F-ara-A.

\section{Effect of intracellular ara-CTP on the accumulation of F-ara-ATP}

The intracellular pharmacokinetics of F-ara-ATP was studied in patients with CLL receiving fludarabine alone or in combination with ara- $\mathrm{C}$ to determine the influence of plasma ara-C and cellular ara-CTP on the accumulation of F-ara-ATP. A comparison of the pharmacokinetic data on F-ara-ATP in circulating leukemic lymphocytes revealed significant changes in patients receiving the combination therapy as compared with those receiving fludarabine alone (Fig. 3A vs Fig. 3B). The peak concentration of 

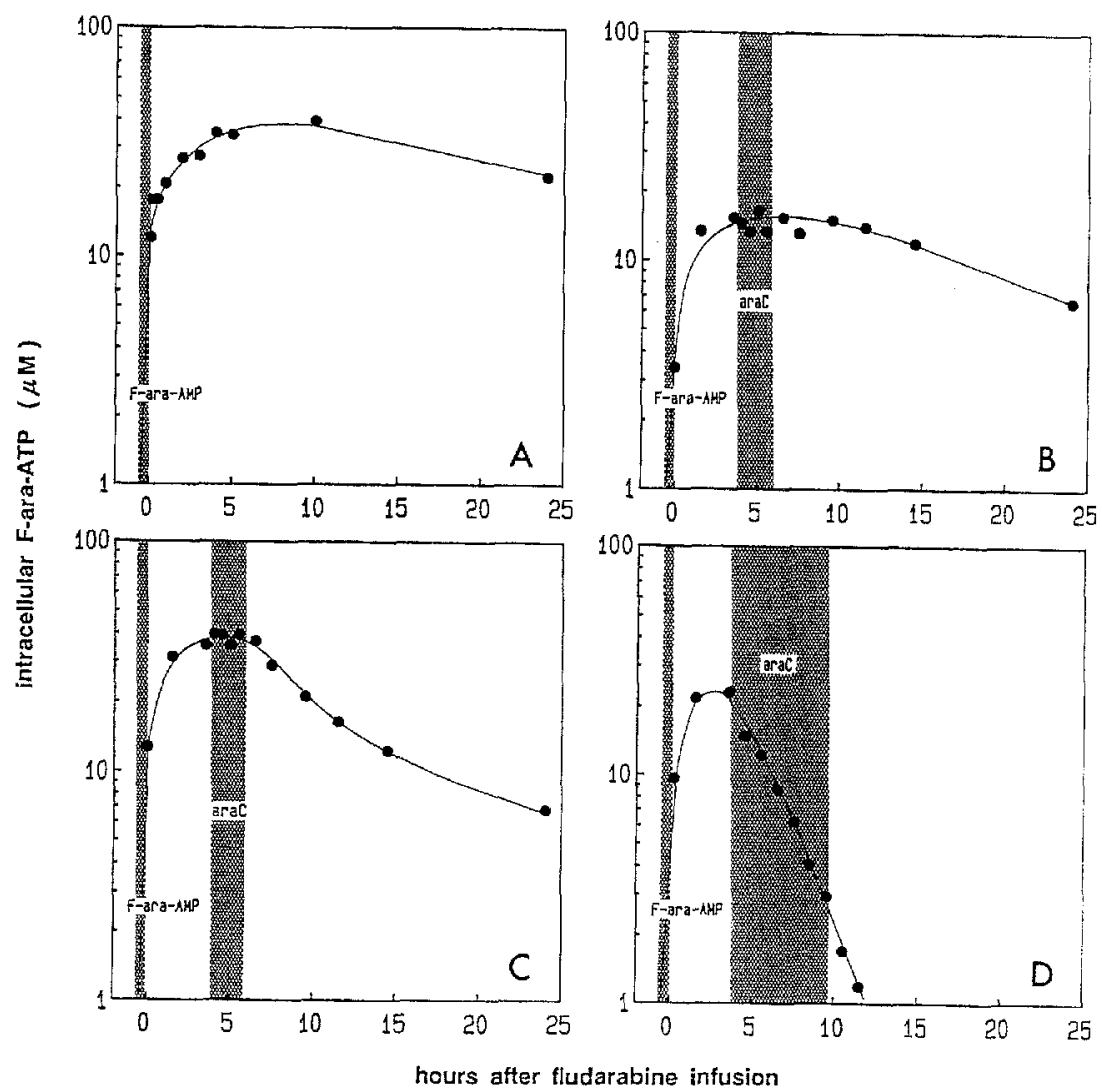

Fig. 3A-D. Concentrations of F-ara-ATP in circulating leukemia cells of four patients diagnosed with $\mathbf{A}$, B CLL or C, D acute leukemia were monitored over $24 \mathrm{~h}$ starting at the end of a 30 -min $\mathrm{i}$. v. infusion of $30 \mathrm{mg} / \mathrm{m}^{2}$ fludarabine $(F$-ara-AMP). Patients received fludarabine either $\mathbf{A}$ alone or in combination with two infusions of ara-C given (at $20 \mathrm{~h}$ before and $4 \mathrm{~h}$ after fludarabine) at doses of $\mathbf{B}$ $0.5 \mathrm{~g} / \mathrm{m}^{2}$ over $2 \mathrm{~h}, \mathbf{C ~} 1 \mathrm{~g} / \mathrm{m}^{2}$ over $2 \mathrm{~h}$, and D $3 \mathrm{~g} / \mathrm{m}^{2}$ over $6 \mathrm{~h}$
F-ara-ATP in CLL cells was $43 \%$ lower $(P=0.056)$ following combination therapy as compared with fludarabine monotherapy (Table 1). The time to reach maximal F-araATP concentrations was not changed $(3 \pm 1 \mathrm{~h}$ after the start of the infusion in both groups; data not shown). These data agree with previous in vitro studies, which indicate that preloading of cells with ara-CTP inhibits the rate of accumulation of F-ara-ATP [14]. Although the ara-CTP concentrations in CLL lymphocytes ranged between 8 and $63 \mu \mathrm{M}$ prior to the fludarabine infusion (Table 1), no relationship was observed in these seven patients between the ara-CTP concentration and the subsequent peak F-ara-ATP accumulation as compared in the same individuals. Additionally, these studies indicated that F-ara-ATP elimination tended to be more rapid in leukemic lymphocytes after ara- $\mathrm{C}$ infusion $(P=0.109$; Table 1$)$. As a consequence of lower $\mathrm{C}_{\max }$ values and faster elimination of the $\mathrm{F}$-ara-ATP, the mean total AUC for F-ara-ATP over $24 \mathrm{~h}$ was $58 \%$ lower $(P=0.050$; Table 1$)$ in CLL cells exposed to both ara-C and fludarabine as compared with fludarabine alone.

The study design for acute leukemias precluded a direct comparison of F-ara-ATP pharmacokinetics in blasts following treatment with fludarabine alone or in combination with ara-C. However, considerable changes in the pharmacokinetics of F-ara-ATP were observed with increasing ara-C doses (Figs. 3C, D). At $3 \mathrm{~g} / \mathrm{m}^{2}$ ara-C infused over $6 \mathrm{~h}$, the mean peak level of F-ara-ATP was $44 \%$ $(P=0.052)$ of that measured in blasts from patients who had received $1 \mathrm{~g} / \mathrm{m}^{2}$ over $2 \mathrm{~h}$ (Table 1 ). The time to reach maximal F-ara-ATP levels was similar in both cases (data not shown). The mean ara-CTP concentrations remaining after the first ara-C infusion of either $1 \mathrm{~g} / \mathrm{m}^{2}$ over $2 \mathrm{~h}$ or

Table 1. Pharmacokinetics of F-ara-ATP in leukemia cells after ara-C infusion

\begin{tabular}{|c|c|c|c|c|c|c|c|}
\hline \multirow[t]{2}{*}{ Disease } & \multirow{2}{*}{$\begin{array}{l}\text { Ara-C dose } \\
\left(\mathrm{mg} / \mathrm{m}^{2}\right)\end{array}$} & \multirow[t]{2}{*}{$n$} & \multicolumn{3}{|l|}{ F-ara-ATP } & \multirow{2}{*}{$\begin{array}{l}\text { Ara-C } \mathrm{Css}_{\mathrm{s}} \mathrm{b} \\
(\mu \mathrm{M})\end{array}$} & \multirow{2}{*}{$\begin{array}{l}\text { Ara-CTPs } \\
(\mu \mathrm{M})\end{array}$} \\
\hline & & & $\begin{array}{l}\mathrm{C}_{\max } \\
(\mu \mathrm{M})\end{array}$ & $\begin{array}{l}t_{1 / 2} \\
(\mathrm{~h})\end{array}$ & $\begin{array}{l}\text { AUC } \\
\left(\mu_{M} h\right)\end{array}$ & & \\
\hline CLL & 0 & 6 & $45.4 \pm 30.3$ & $36.5 \pm 21.1$ & $880 \pm 435$ & - & - \\
\hline CLL & $0.5(2)$ & 7 & $19.4 \pm 10.1$ & $18.5 \pm 8.5$ & $372 \pm 272$ & $13 \pm 4$ & $35.7 \pm 20.9$ \\
\hline $\mathrm{AL}$ & $1.0(2)$ & 6 & $31.6 \pm 18.9$ & $3.8 \pm 1.9^{\mathrm{d}}$ & $401 \pm 152$ & $23 \pm 8^{\mathrm{e}}$ & $24.7 \pm 18.3$ \\
\hline
\end{tabular}

a Numbers in parentheses represent the duration of infusion in hours

$b$ Median steady-state ara-C concentration in plasma during infusion of

d $t_{1 / 2} \beta=29.4 \pm 16.4 \mathrm{~h}$

the second ara-C dose at $4 \mathrm{~b}$ after the administration of fludarabine

e $n=5$

c Ara-CTP remaining in leukemia cells from the first ara-C infusion as

AL, Acute leukemias

measured at the time of fludarabine infusion 


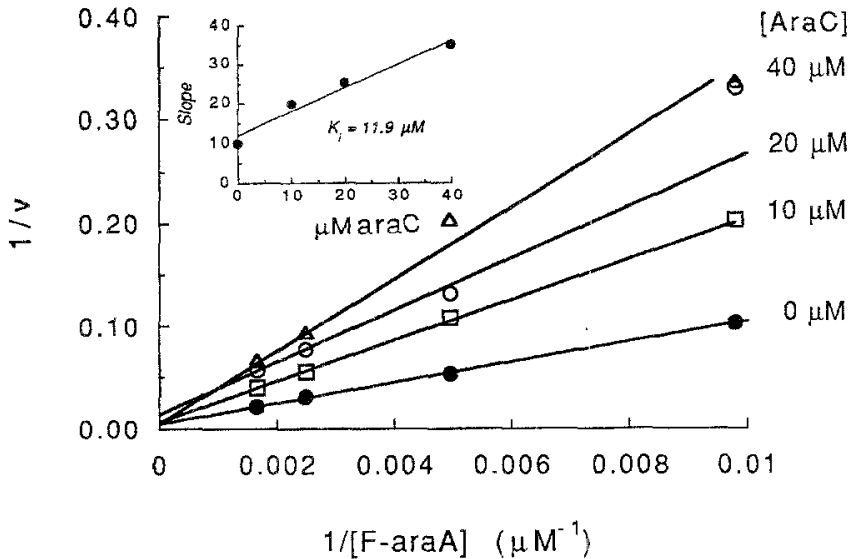

Fig. 4. Inhibition of dCyd kinase phosphorylation of F-ara-A by ara-C. Purified human dCyd kinase was incubated with $\left[{ }^{3} \mathrm{H}\right] \mathrm{F}$-ara-A alone $(\bullet)$ or in the presence of ara-C at $10(\square), 20(O)$, or $40 \mu \mathrm{M}(\Delta)$. Data points represent mean values for duplicate determinations. Inset: Replot of the slope of each line against the ara-C concentrations

$3 \mathrm{~g} / \mathrm{m}^{2}$ over $6 \mathrm{~h}$ prior to fludarabine administration did not significantly differ $(P=0.757$; Table 1$)$. F-ara-ATP elimination after the lower ara-C dose was biphasic, with a mean $t_{1 / 2} \alpha$ value of $3.8 \pm 1.9 \mathrm{~h}$ and a mean $t_{1 / 2} \beta$ value of $29.4 \pm 16.4 \mathrm{~h}$ being obtained (Fig. 3C). Treatment with $3 \mathrm{~g} / \mathrm{m}^{2}$ ara-C resulted in a comparatively short monophasic elimination (mean $t 1 / 2,3.3 \pm 1.1 \mathrm{~h}$ ), and F-ara-ATP could no longer be detected at about $12 \mathrm{~h}$ after the fludarabine infusion (Fig. 3D). These findings indicate that infusion of ara-C altered the elimination kinetics of F-ara-ATP in circulating blasts. As a consequence, the mean AUC for F-ara-ATP in blasts of patients who received $3 \mathrm{~g} / \mathrm{m}^{2}$ ara-C over $6 \mathrm{~h}$ was $25 \%(P=0.007)$ of that determined for patients treated with $1 \mathrm{~g} / \mathrm{m}^{2}$ over $2 \mathrm{~h}$.

\section{Inhibition of $F$-ara-A phosphorylation by ara-C using purified dCyd kinase}

During the ara-C infusions, steady-state plasma concentrations of ara-C were substantially higher $(13 \pm 14 \mu \mathrm{M}$, $23 \pm 8 \mu \mathrm{M}$, and $27 \pm 9 \mu \mathrm{M}$; Table 1) at ara-C doses of 0.5 , 1.0 , and $3.0 \mathrm{~g} / \mathrm{m}^{2}$, respectively, than those of $\mathrm{F}$-ara-A, which were less than $1 \mu \mathrm{M}$ at each dose. Because ara-C is a better substrate for phosphorylation by $\mathrm{dCyd}$ kinase, phosphorylation of F-ara-A in plasma would be inhibited in the presence of ara-C. This may in part explain the observed perturbations in plasma F-ara-A and cellular F-ara-ATP pharmacokinetics during ara-C infusions.

For exploration of this hypothesis, dCyd kinase purified from a murine L-cell expression system containing the cDNA sequence for human T-lymphoblast dCyd kinase was used to determine the inhibitory effect of ara-C on F-ara-A phosphorylation using ATP as the phosphate donor. A Lineweaver-Burk plot of the data revealed an apparent $K_{\mathrm{m}}$ value (Michaelis constant) of $1600 \mu \mathrm{M}$ for F-ara-A. Ara-C was a competitive inhibitor of F-ara-A phosphorylation, with a $K_{\mathrm{i}}$ value of $11.9 \mu \mathrm{M}$ being obtained (Fig. 4). By comparison, the $K_{\mathrm{m}}$ of dCyd kinase for ara-C in the same system was $14.8 \mu \mathrm{M}$.

\section{Discussion}

The interference of ara-C with $\mathrm{F}$-ara-A metabolism in vivo was directly visualized by measuring $\mathrm{F}$-ara-A plasma pharmacokinetics during ara-C infusion. A transient increase or a plateau of the F-ara-A plasma levels was observed at the onset of the ara-C infusion (Fig. 1B-D), Fig. 2A). Subsequently, the terminal half-life of F-ara-A was reduced in proportion to the plasma concentration of ara-C (Fig. 2B). This disturbance of the usual triphasic elimination kinetics of F-ara-A (Fig. 1 A) suggests a redistribution of F-ara-A from the tissues into the plasma.

The terminal half-life of a drug in plasma reflects an equilibrium between the retention of the compound in the tissue and its excretion. This was previously shown to be independent of fludarabine concentration in a dose range of between 80 and $260 \mathrm{mg} / \mathrm{m}^{2}$ [27]. Under the conditions of therapy, the elimination kinetics of the drug in tissue, measured as the $t_{1 / 2}$ of F-ara-ATP in circulating leukemia cells, decreased considerably when ara-C was added to the regimen (Fig. 3, Table 1). The faster elimination of F-ara-A from plasma after treatment with ara-C (Fig. 2B) therefore reflects a shorter retention of the drug in the tissue. In an earlier investigation using higher fludarabine doses $\left(50-100 \mathrm{mg} / \mathrm{m}^{2}\right)$, pharmacokinetic studies in circulating blasts of eight patients with acute leukemia showed monophasic elimination of F-ara-ATP, with half-lives ranging between 5.2 and over $24 \mathrm{~h}$ (mean, $15.1 \pm 8.0 \mathrm{~h}$; median, $13.5 \mathrm{~h}$ [8]). This suggests that acute leukemia blasts eliminate F-ara-ATP more rapidly than do CLL lymphocytes (Table 1). Additionally, ara-C infusion perturbed the elimination kinetics of F-ara-ATP, an action that was dependent on the duration of the ara-C infusion. In K562 cells, the elimination kinetics of F-ara-ATP were not changed by prior incubation with ara-C [14]. The experimental conditions, however, differed from the in vivo situation in that the dose of F-ara-A was 30-fold that of ara-C and the cells were washed free of ara-C prior to the addition of F-ara-A.

As predicted from the preclinical data $[14,15]$, CLL cells accumulated less F-ara-ATP when the patients had received ara-C at $20 \mathrm{~h}$ prior to fludarabine administration (Fig. 3A, B). In patients with acute leukemias, two higher ara-C dose levels $\left(1 \mathrm{~g} / \mathrm{m}^{2}\right.$ over $2 \mathrm{~h}$ and $3 \mathrm{~g} / \mathrm{m}^{2}$ over $6 \mathrm{~h}$ ) were combined with the standard fludarabine dose (30 $\mathrm{mg} / \mathrm{m}^{2}$ over $30 \mathrm{~min}$ ). Because fludarabine as a single agent had shown no clinical efficacy in acute leukemias at this dose [33] and was used to modulate ara-C metabolism in our treatment protocols, the protocol design precluded the study of peak F-ara-ATP concentrations in cells that had not previously been exposed to ara-C. However, the median $\mathrm{C}_{\max }$ of accumulated F-ara-ATP in patients who received the higher ara- $\mathrm{C}$ dose was considerably lower $(60 \%)$ than that in patients treated with the lower ara-C dose (Table 1). A likely explanation for this effect would be a feedback inhibition of dCyd kinase by ara-CTP [7, 14, 28]. In cell-free extracts of $\mathrm{K} 562$ cells, the activity of dCyd kinase was previously inhibited by the addition of $100 \mu \mathrm{M}$ ara-CTP [14]. Thus, it is possible that the ara-CTP concentrations at the time of fludarabine infusion [range, $8-63 \mu \mathrm{M}(n=7)$; Table 1] were sufficient to exert feedback inhibition of dCyd kinase in the clinical setting [17]. 
It seems rather unlikely that the peak concentration of F-ara-ATP was influenced by the second ara-C dose given at $4 \mathrm{~h}$ after the start of the fludarabine infusion, as the time to reach peak F-ara-ATP concentrations was the same $(3 \pm 1 \mathrm{~h})$ in patients treated in the presence versus the absence of additional ara-C.

The following mechanisms should be considered as explanations for the ara-C-induced perturbations in plasma F-ara-A and, consequently, the pharmacokinetics of F-araATP in leukemia cells. First, consider renal excretion, which is the major route of F-ara-A elimination [23, 27]. Although deamination is responsible for ara-C clearance, the deamination product arabinosyluracil, a substrate for renal excretion, had reached plasma levels of between 50 and $250 \mu \mathrm{M}$ by the end of the ara-C infusions [17]. Had the renal excretion mechanism been saturated by arabinosyluracil, a plateau followed by a prolonged terminal halflife would have been expected rather than the observed increase in $\mathrm{F}$-ara-A plasma levels followed by their rapid elimination (Fig. 1, Table 1). Furthermore, prolonged elevation of F-ara-A plasma levels should have translated into higher rather than lower intracellular concentrations of F-ara-ATP. Therefore, it is unlikely that a competition between the two drugs for renal excretion sites was responsible for the altered F-ara-A elimination kinetics.

Second, the possibility of F-ara-A release from leukemia cells as a consequence of rapid cell kill caused by ara-C is unlikely because the increase in F-ara-A plasma concentrations was measurable at $30 \mathrm{~min}$ after the onset of the ara-C infusion. An increase in plasma levels of 2chlorodeoxyadenosine was previously observed upon lysis of CLL cells, but it occurred several days after drug infusions [4]. In contrast, no significant decrease in the number of leukemia cells was observed at the time at which plasma F-ara-A levels increased.

Competition of the two nucleosides for transport into cells represents a third possibility of explaining the increase in plasma F-ara-A during ara-C infusion. It is likely that both F-ara-A and ara-C are substrates for the same high-capacity facilitated diffusion mechanism [31, 34]. At the time of ara-C infusion, plasma levels of F-ara- $A$ ranged between 0.3 and $0.7 \mu \mathrm{M}$ (Fig. 1). In contrast, ara-C concentrations ranged from 16 to $61 \mu \mathrm{M}$, levels that might be expected to result in effective competition with $\mathrm{F}$-ara-A for entry into cells.

Finally, because both ara- $\mathrm{C}$ and $\mathrm{F}$-ara-A are phosphorylated by dCyd kinase, a competition for this enzyme is likely. The greater affinity of dCyd kinase for ara-C $\left(K_{\mathrm{m}}=15-41 \mu \mathrm{M}[5,9,11,26]\right.$; present study $)$ as compared with F-ara-A $\left(K_{\mathrm{m}}=290-1600 \mu \mathrm{M}[2,16]\right.$; present study $)$ and the differences in plasma concentrations (ara-C levels were 20-50 times greater than those of F-ara-A) support this interpretation. Furthermore, ara-C was found to competitively inhibit $\mathrm{F}$-ara-A phosphorylation in an in vitro experiment using purified dCyd kinase (Fig. 4). Ara-C concentrations in the range of the $K_{\mathrm{i}}$ value determined in this experiment $(11.9 \mu \mathrm{M})$ were reached or exceeded in the plasma of patients treated with either 0.5 or $1 \mathrm{~g} / \mathrm{m}^{2}$ over $2 \mathrm{~h}$ $\left(13 \pm 4 \mu \mathrm{M}\right.$ and $23 \pm 8 \mu \mathrm{M}$, respectively) or $3 \mathrm{~g} / \mathrm{m}^{2}$ over $6 \mathrm{~h}$ $(27 \pm 9 \mu \mathrm{M} ;$ Table 1$)$. In addition, the activity of dCyd kinase may be inhibited by ara-CTP [7, 14, 28]. The ara-CTP concentrations present at the time of fludarabine infusion (Table 1) lay within the range reported to affect the activity of dCyd kinase.

In conclusion, the inhibitory effect of ara-C on the accumulation of F-ara-ATP found in preclinical experiments using leukemia cells was confirmed in the clinical setting by the present study. On the basis of the considerations discussed above, in a protocol using F-ara-A as a biochemical modulator of ara-C, the ara-C should be given as a relatively short-term (e.g., 2-4 h) infusion following fludarabine. This design would help to minimize metabolic interference with the subsequent fludarabine dose.

Acknowledgements. The authors are grateful to Ms. M. Du, Ms. K. Faucher, Ms. A. Keating, Ms. H. Pike, Ms. K. Reynolds, and Mr. C. Rolf for their excellent technical assistance and to Ms. G. Nesom for her editorial assistance in the preparation of the manuscript.

\section{References}

1. Breithaupt $\mathrm{H}$ (1981) Determination of cytarabine and uracil arabinoside in human plasma and cerebrospinal fluid by high-performance liquid chromatophraphy. I Chromatogr 225: 99- 106

2. Brockman RW, Cheng Y-C, Schabel FM, Montgomery JA (1980) Metabolism and chemotherapeutic activity of $9-\beta$-D-arabinofuranosyl-2-fluoroadenine against murine leukemia $\mathrm{L} 1210$ and evidence for its phosphorylation by deoxycytidine kinase. Cancer Res 40 : 3610-3615

3. Brown RD, Manno JE (1978) ESTRIP, a BASIC computer program for obtaining initial polyexponential parameter estimates. J Pharm Sci 67: $1687-1691$

4. Carson DA, Wasson DB, Beutler E (1984) Antileukemic and immunosuppressive activity of 2 -chloro-2'-deoxyadenosine. Proc Natl Acad Sci USA 81: $2232-2236$

5. Cheng Y'-C, Domin B, Lee L-S (1977) Human deoxycytidine kinase. Purification and characterization of the cytoplasmic and mitochondrial isozymes from blast cells of acute myelocytic leukemia patients. Biochim Biophys Acta 481: 481-492

6. Chottiner EG, Shewach DS, Datta NS, Ashcraft E, Gribbin D, Ginsburg D, Fox IH, Mitchell BS (1991) Cloning and expression of human deoxycytidine kinase cDNA. Proc Natl Acad Sci USA 88: $1531-1535$

7. Coleman CN, Stoller RG, Drake JC, Chabner BA (1975) Deoxycytidine kinase: properties of the enzyme from human leukemic granulocytes. Blood 46: 791-803

8. Danhauser L, Plunkett W, Keating M, Cabanillas F (1986) 9- $\beta$-DArabinofuranosyl-2-fluoroadenine 5 '-monophosphate pharmacokinetics in plasma and tumor cells of patients with relapsed leukemia and lymphoma. Cancer Chemother Pharmacol 18: 145-152

9. Datta MS, Shewach DS, Mitchell BS, Fox IH (1989) Kinetic properties and inhibition of human T-lymphoblast deoxycytidine kinase. J Biol Chem 264: $9359-9364$

10. Dow LW, Bell DE, Poulakos L, Fridland A (1980) Differences in metabolism and cytotoxicity between $9-\beta$-D-arabinofuranosyladenine and $9-\beta$-D-arabinofuranosyl-2-fluoroadenine in human leukemic lymphoblasts. Cancer Res 40: $1405-1410$

11. Durham JP, Ives DH (1969) Deoxycytidine kinase: I. Distribution in normal and neoplastic tissues and interrelationships of deoxycytidine and 1- $\beta$-D-arabinofuranosylcytosine phosphorylation. Mol Pharmacol 5: $358-375$

12. Estey E, Plunkett W, Dixon DO, MoCredie K, Freireich EJ (1987) Variables predicting response to high dose cytosine arabinoside therapy with refractory acute leukemia. Leukemia 1: 580-583

13. Estey EH, Keating MJ, McCredie KB, Freireich EJ, Plunkett W (1990) Cellular ara-CTP pharmacokinetics, response, and karyotype in newly diagnosed acute myelogenous leukemia. Leukemia 4: 95-99 
14. Gandhi V, Plunkett W (1988) Modulation of arabinosyl nucleoside metabolism by arabinosylnucleotides in human leukemia cells. Cancer Res 48: 329-334

15. Gandhi V, Nowak B, Keating MJ, Plunkett W (1989) Modulation of arabinosylcytosine metabolism by arabinosyl-2-fluoroadenine in lymphocytes from patients with chronic lymphocytic leukemia: implications for combination therapy. Blood 74: 2070-2075

16. Gandhi V, Estey E, Keating MJ, Plunkett W (1991) Synergistic combination of fludarabine and ara-C for AML therapy. Blood 78 [Suppl 1]: 52a

17. Gandhi V, Kemena A, Keating MJ, Plunkett W (1992) Fludarabine infusion potentiates arabinosylcytosine metabolism in lymphocytes of patients with chronic lymphocytic leukemia. Cancer Res 52: 897-903

18. Kantarjian HM, Estey EH, Plunkett W, Keating MJ, Walters RS, Iacoboni S, McCredie KB, Freireich EJ (1986) Phase I-II clinical and pharmacologic studies of high-dose cytosine arabinoside in refractory leukemia. An J Med 81: 387-394

19. Keating MJ, McCredie KB, Bodey GP, Smith TL, Gehan EA, Freireich EJ (1982) Improved prospects for long-term survival in adults with acute myelogenous leukemia. JAMA 248: 2481-2486

20. Keating MJ, Kantarjian H, Talpaz M, Redman J, Koller C, Barlogie B, Velasquez W, Plunkett W, Freireich EJ, McCredie KB (1989) Fludarabine monophosphate: a potentially useful agent in chronic lymphocytic leukemia. Blood 74: 19-25

21. Keating MJ, Kantarjian H, O'Brien S, Koller C, Talpaz M, Koller C, Schachner J, Childs CC, Freireich EJ, McCredie KB (1991) Fludarabine: a new agent with marked cytoreductive activity in untreated chronic lymphocytic leukemia. J Clin Oncol 9: 44-49

22. Kemena A, Fernandez M, Bauman J, Keating M, Plunkett W (1991) A sensitive fluorescence assay for quantitation of fludarabine and metabolites in biological fluids. Clin Chim Acta 200: 95-106

23. Kemena A, Keating MJ, Plunkett W (1991) Plasma and cellular bioavailability of oral fludarabine. Blood 78 [Suppl 1]: 52a

24. Kessel D, Hall TG, Wodinsky I (1967) Transport and phosphorylation as factors in the antitumor action of cytosine arabinoside. Science 156: $1240-1241$
25. Kim M-Y, Iyes DH (1989) Human deoxycytidine kinase: kinetic mechanism and end product regulation. Biochemistry 28: $9043-$ 9047

26. Krenitsky TA, Tuttle JV, Koszalka CW, Chen IS, Beacham LM, Rideout J, Elion GB (1976) Deoxycytidine kinase from calf thymus. Substrate and inhibitor specificity. J Biol Chem 251: $4055-4061$

27. Malspeis L, Grever MR, Staubus AE, Young D (1990) Pharmacokinetics of 2-F-ara-A ( $9-\beta$-D-arabinofuranosyl-2-fluoroadenine) in cancer patients during the phase I clinical investigation of fludarabine phosphate. Semin Oncol 17 [Suppl 8]: 18-32

28. Momparler RL, Brent TP, Labitan A, Krygier V (1971) Studies on the phosphorylation of cytosine arabinoside in mammalian cells. Mol Pharmacol 7: $413-419$

29. Novotný L, Plunkett W (1990) Synthesis of 9- $\beta$-D-arabinofuranosyl2-fluoroadenine 5 'triphosphate. In: Townsend LB, Tipson RS, (eds) Nucleic acid chemistry, part 4. John Wiley and Sons, New York, pp 337-340

30. Plunkett W, Iacoboni S, Estey E, Danhauser L, Liliemark JO, Keating MJ (1985) Pharmacologically directed ara-C therapy for refractory leukemia. Semin Oncol 12 [Suppl 1]: 20-30

31. Sirotnak FM, Chello PL, Dorick DM, Montgomery JA (1983) Specificity of systems mediating transport of adenosine, 9- $\beta$-D-arabinofuranosyl-2-fluoroadenine, and other purine nucleoside analogues in L1210 cells. Cancer Res 43: 104- 109

32. Tseng W-C, Derse D, Cheng Y-C, Brockman RW, Bennett LL Jr (1982) In vitro biological activity of 9- $\beta$-D-arabinofuranosyl-2fluoroadenine and the biochemical actions of its triphosphate on DNA polymerases and ribonucleotide reductase from HeLa cells. Mol Pharmacol 21: 474-477

33. Warrell RP, Berman E (1986) Phase I and II study of fludarabine phosphate in leukemia: therapeutic efficacy with delayed central nervous system toxicity. J Clin Oncol 4: 74-79

34. Wiley JS, Jones SP, Sawyer WH, Paterson ARP (1982) Cytosine arabinoside influx and nucleoside transport sites in acute leukemia. J Clin Invest 69: 479-489

35. Wilkinson GN (1961) Statistical estimations in enzyme kinetics. Biochem J 80: 324-332 